\title{
Zpráva o konferenci BTC
}

\section{Martin Hanoušek / Věra Velemanová}

Brno Theatralia Conference. Katedra divadelních studií. Filozofická fakulta. Masarykova univerzita. Brno. 1.-3. června 2021. Online.

Brno Theatralia Conference, akce organizovaná Katedrou divadelních studií Masarykovy univerzity, je už tradičním a dychtivě očekávaným setkáním odborníků na mezinárodní úrovni s velmi kvalitním doprovodným programem. Letošní ročník, který byl zasvěcen problematice avantgardy, se měl uskutečnit v r. 2020 k připomenutí stoletého výročí vzniku Svazu moderní kultury Devětsil (5. 10. 1920), bohužel musel být ze známých důvodů o rok odložen a odehrál se pouze formou on-line propojení, ale ani to mu neubralo na přitažlivosti a pestrosti. Mezi dvaceti jedna řečníky byli jak tuzemští pedagogové a badatelé, tak referenti ze zahraničí, od zemí střední a východní Evropy (Polsko, Ukrajina), přes Francii a Portugalsko po Spojené státy americké a Indii.

Úvodní den konference Czech Historical Avant-garde in the European Context zahájil příspěvek prvního z hlavních mluvčích, polského teatrologa Dariuzse Kosinského z Jagellonské univerzity v Krakowě „Central European Theatre Avant-garde in the European Context“. Autor v něm poodkryl pozadí, zázemí či úskalí výzkumného projektu o avantgardě střední a východní Evropy, jenž by měl být dokončen v r. 2023 vydáním publikace: Lexikon of the CentralEastern European Avant-garde. Přiblížil kroky předcházející tomuto projektovému záměru, konferenci, věnovanou ukrajinskému avantgardnímu divadelníkovi Lesi
Kurbasovi v r. 2010 či stoleté výročí avantgardy v Polsku v r. 2017, s publikačním výstupem v knize Reclamed Avant-garde: Spaces and Stages of Avant-garde Theatre in Central-Eastern Europe, sdružující důležité texty avantgardního hnutí států tohoto teritoria, vč. Československa nebo např. pobaltských zemí. Součástí cesty k uskutečnění výše zmíněného výzkumného projektu byla v roce 2018 také varšavská konference o prostoru a scéně avantgardního divadla, tentokrát již s účastí odborné veřejnosti z Běloruska nebo Gruzie. Koncipování lexikonu se podle Kosinského potýká s některými metodologickými problémy, zejména, pokud jde o definování avantgardy, nebot představuje cosi nepevného, neurčeného, spíše je výrazem soustavného tvůrčího procesu výzkumného vztahu vůči ní. Za zásadní věc badatelského zájmu o avantgardu střední a východní Evropy autor považuje podobný historický vývoj v příslušných zemích, neustále hledajících, ztrácejících a znovu nalézajících svoji nezávislost. $\mathrm{Z}$ toho také odvozuje jejich pozitivní poměr $\mathrm{k}$ avantgardě jakožto předmětu hledání svébytné společenské identity.

\section{Theoretical Concepts of Avant-garde I}

Příspěvek Hany Veselovské z Ukrajinské národní galerie umění s názvem 
„Technicism in the Avant-garde Theatre (The Clash of Meanings and Forms)“ pojednával ukrajinskou avantgardu dvojí optikou, z pohledu propagandy techniky (technického pokroku) a využití techniky v divadle. Své poznatky přednášející doložila ukázkami z několika inscenací např. režiséra Olexandera Chvostěnka-Chvostova a jeho adaptacemi děl Uptona Sinclaira.

V referátu Jindřicha Tomana (předního znalce středoevropské avantgardní knižní kultury) „Shifting Structures, Asymmetric Networks" se autor pokusil načrtnout charakter vzájemných vztahů a výměny informací a zkušeností mezi skupinami a sdruženími avantgardy československé a zahraniční. Pracoval přitom s pojmy centrum, tj. ústředí činnosti dotyčného uskupení s dalším možným rozlišením na centrum mezinárodní a národní, jenž v jeho uvažování nejsou totožné, a periferie, tj. okrajovější skupina, hnutí nebo část hnutí, která se vůči centru nějak projevuje a vztahuje se k němu. Za příklad mezinárodního centra označuje Paříž, kam umělci odjížděli, pokud usilovali být ve středu tehdejšsího uměleckého života, z Československa např. Jindřich Štyrský a Toyen. Své postřehy dokumentoval na spolku Devětsil, sdružení Levá fronta, kulturní organizaci se vztahem k avantgardě, a Českém surrealismu, kde tezi o asymetrii vztahů s pařížským surrealistickým centrem vyvrátil návštěvou André Bretona a Paula Eluarda v Praze r. 1935.

Martin Bernátek z Katedry divadelních a filmových studií FF UP v Olomouci hovořil ve svém referátu „Theatre Architecture for the Avant-garde“ o spojení avantgardního divadla a architektury s širokým polem možností uchopení scénického prostoru (otáčivé jeviště). Tato symbióza měla vyjadřovat vnímání nové reality avantgardou a scénické postupy měly být prostředkem této reflexe. Jako příklad avantgardního sepětí architektury a divadla zmínil návrh Devětsilbühne (Jeviště v představách sdružení Devětsil) skladatele Miroslava Ponce nebo návrh otáčivé scény (The Round Stage) Zdeňka Pešánka z r. 1926.

\section{Theoretical Concepts of Avant-garde II}

Název příspěvku Andrey Jochmanové z Oddělení dějin divadla MZM v Brně „Wir haben kein Theater" byl nadpisem článku z periodika Pásmo, v němž autoři posuzovali ve dvacátých letech stav divadla v Československu a apelovali na zlepšení stávající situace, kterou považovali za úpadkovou. Do této situace nastoupila avantgarda s řadou inovativních teoretických a praktických myšlenek. Autorka hovořila nejen o průkopnických osobnostech tohoto hnutí, ale i o těch, kteří jejich zkušenosti, myšlení, praxi a př́istup k divadlu zásadně formovali. Například u Jiřího Frejky se jednalo o inspiraci Bauhausem nebo Vachtangovovými inscenacemi (Princezna Turandot); v Rusku narozený Vladimír Gamza, který v r. 1924 otevřel se studenty pražské konzervatoře České studio, byl žákem Vachtangova a Suleržického, jejichž inspirativní divadelní postupy si osvojil, přetavil ve vlastní umělecký styl a vnesl tak do českého avantgardního divadla během svého krátkého působení životodárný proud. Z teoretických úvah, rezonujících v mnoha textech a publikacích (např. Roztočené jeviště Jindřicha Honzla), vznikaly odvážné divadelní formy, např. syntetické revue v Divadle Dada, spojující výrazové složky tance, pantomimy, práci s hlasovou modulací apod. Odlišná stylizace divadla avantgardy pak měla ve vztahu k divákům 
provokovat obecenstvo užíváním metafor.

Tématem souvztažnosti avantgardního divadla a obecenstva se zabýval také referát Yany Partoly z Katedry divadla Kotlyarevského národní univerzity umění v Charkově „Avant-garde Theatre and Audience“. Přednášející v něm mj. hovořila o požadavcích zpětné vazby publika divadelnímu souboru v ukrajinském avantgardním divadle, což prezentovala na př́íkladu Divadla Berezil, které pracovalo s důkladně vypracovaným systémem otázek s cílem zjistit dojem obecenstva ze zhlédnutého představení.

Referát Martiny Musilové „Á la recherche du Henri Bergson perdu (Searching for the Trails of Bergsonism in Czech Avant-garde Concepts)“ se dotýkal působení filosofie Henri Bergsona na československou avantgardu s konstatováním, že tyto podněty přetrvávají prakticky dodnes, zejména $\mathrm{v}$ oblasti českého alternativního divadla. Autorka hovořila o třech etapách průniku Bergsonových myšlenek do tuzemského prostředí, dále pak o tom, čím se jeho uvažování do avantgardního divadla promítlo a co česká (československá kultura) v Bergsonově filosofii hledá. Př́chod Bergsonovy filosofie vymezila roky 1900-1920, zmínila překladatelský podíl Karla Čapka nebo stati Karla Teigeho z poloviny dvacátých let, zdůrazňující v kontextu avantgardy bergsonovské osvobození lidské kreativity, vtipu a humoru, jimiž byli ovlivněni např. Jiří Frejka, Jiří Voskovec a Jan Werich. Třetí fázi zkušeností s Bergsonovými myšlenkami a práci s nimi v českém prostředí spatřuje v osobě literárního historika Václava Černého, který se s nimi, stejně jako Jiří Voskovec seznámil během studií ve francouzském Dijonu. Černý Bergsona nejen překládal, ale viděl i určité spojení jeho filosofie s romantismem v Čechách, což vedlo přednášejí- cí k závěru, že česká kultura dost možná hledá v Bergsonově myšlení svůj ztracený romantismus.

Druhý den se konference na rozdíl teoretických bloků prvního dne zaměřila na konkrétní oblasti, jež avantgarda ovlivnila - zejména na loutkové divadlo, režii a scénografii.

Tuto část setkání otevírala přednáška „Avant-garde Theatre and Puppetry: A Reappraisal“ Didiera Plassarda z Univerzity v Montpellier, který představil důležité předchůdce, z nichž čerpala avantgarda jak v loutkovém divadle, tak i v divadle činoherním (např. Ubu Alfreda Jarryho, loutkové divadlo Edwina Lawrence v Oxfordu a další). Ve své obsáhlé přehledové přednášce ukázal na příkladech meziválečné avantgardy, do jaké míry a v jakých konkrétních rysech zasáhly modernistické proudy konce 19. století progresivní divadelní tendence počátku století dvacátého, jak se vyvíjela vizuální podoba loutky těchto období (od tradičních marionet ke stylizované loutce, od narativního divadla k abstrahovaným formám sdělení) a jak se promítl silný vliv avantgardních postupů a forem do současné tvorby.

Jiřina Hofmanová z brněnské JAMU a Masarykovy univerzity se zabývala v př́ispěvku „Avant-garde Directors and Repertory Theatre" režijní tvorbou Jindřicha Honzla a Emila Františka Buriana v Národním divadle v Brně mezi lety 1929 a 1932, zejména inscenacemi komedií, jako byla např. Machiavelliho Mandragora (režie E. F. Burian, scéna A. Heythum, 1929) či Klicperův Hadrián z Římsů (režie J. Honzl, scéna F. Muzika, 1930), jejichž odlišný charakter a humor vyžadoval od režisérů a jejich scénografů pracovat také s rozdíným typem stylizace. 
Iva Mikulová z ÚČL a Masarykovy univerzity si ve svém př́íspěvku „Performative Activities of the Brno Devětsil Circle“ všímala některých aspektů práce brněnského Devětsilu z hlediska srovnání se zahraničními proudy daného období. Reflektovala také snahy této sekce proslulého avantgardního proudu narušit zaběhané konvence divadelního provozu. Hovořila o multiplicitě akcí, které nespočívaly pouze $\mathrm{v}$ divadelních představeních, ale také v přednáškách a výstavách, a vyzdvihla všestrannou výtvarnou podporu Zdeňka Rossmanna, jehož typografické úpravy a scénografie tvořily vizuální základ brněnského okruhu, spolu s tvorbou Karla Teigeho, Jindřicha Honzla, Jaroslava Bohumila Svrčka a dalších.

\section{Scenography and Theatre Objects}

Blok zahajovala Valentyna Chechyk (Institut umění v Charkově) pojednáním „Alexandra Exter's Theatre and Ukrainian Scenography of the 1910-1920s“, které ukázalo na chronicky známém díle proslulé výtvarnice mimo jiné i některé doposud málo akcentované rysy, související $\mathrm{s}$ její příslušností k ukrajinskému národu a s tím, že umělkyně dopodrobna znala ukrajinskou lidovou kulturu, jejíž prvky ve stylizované podobě využila ve svých scénických a kostýmních návrzích. Ukázala zde také tvorbu v Evropě nezaslouženě méně známých ukrajinských výtvarníků, jako byl např. Vladimir Müller.

Monica Yadav (doktorandka na Nehruově univerzitě v Dillí) se v příspěvku „Emergence of Theatre Object as a Repository of Memory: An Investigation into Tadeusz Kantor's Practice of Inter/Post-World War Theatre“ věnovala otázkám spojeným s tvorbou T. Kantora z hlediska kolektivní paměti, zápasící s traumaty války a dalších destruktivních událostí a z hlediska zpo̊sobu řeči, metafory, kterou ve svém díle tvůrce volí pro vyjádření těchto traumat.

Vlasta Koubská z pražské DAMU se dlouhodobě zabývá mj. tvorbou Antonína Heythuma, kterého na konferenci představila ve svém příspěvku „Antonín Heythum (1901-1954): Stage Designer, Architect, Industrial Designer". Mluvila mimo jiné o tom, že během své práce narazila na cenné materiály z rodinného archivu, ozřejmující další souvislosti jeho meziválečné tvorby v Československu či například na jeho přednášky ze třicátých let, jejichž rukopis se nachází v soukromé sbírce. Heythumova tvorba, ač výjimečná a pro avantgardu jako celek určující, byla dlouho v pozadí zájmu oproti tvorbě jiných avantgardních výtvarníků, zejména kvůli emigraci a jeho poválečnému angažmá v USA.

Druhý den konference uzavíral off program v podobě videonahrávky opery Bohuslava Martinů Tři př́ni aneb Vrtkavosti života $\mathrm{v}$ režii Jiř́ího Nekvasila a scénografii Daniela Dvořáka (Národní divadlo moravskoslezské v Ostravě, 2015) se zasvěceným komentářem operní dramaturgyně a pedagožky Heleny Spurné. Opera je pozoruhodná zasazením děje do filmových ateliérů a spoluprací Bohuslava Martinů s předním představitelem dadaismu, spisovatelem, malířem, hudebníkem a libretistou Georgesem Ribemontem-Dessaignesem. Inscenačně je velkou výzvou ve smyslu paralelnosti několika dějových a lokálních pásem, které právě Nekvasilova režie dokázala s úspěchem pojmout.

Den třetí začal přednáškou „Upside-down Theatre. Lettrism and the Legacy of Dada and Surrealism Avant-gardes“ (1945-1968) 
Fabrice Flahuteze $\mathrm{z}$ Univerzity $\mathrm{v}$ Lyon-Saint-Etienne.

Přednáška se věnovala pozoruhodnému směru, lettrismu, který v rámci avantgardy zaujímá své zvláštní místo, a jehož základy vznikly po druhé světové válce v Paříži, ovšem coby životaschopný proud zasáhl lettrismus např. i české výtvarné umění v osobě Jiřího Koláře, Josefa Hiršala, Eduarda Ovčáčka a dalších. Flahutez si ovšem všímal i divadelních projevů, které byly lettrismem zasaženy - kdy je slovník na divadle dekonstruován, zkoušen, a kdy se tak odhalují mimo jiné na jedné straně úskalí slova (které nemusí být vždy prostředkem dorozumívání, ale naopak zastírání a odcizení), na druhé straně jeho nekonečné možnosti, jichž umění může využívat (posunování významu, překrývání významů, změny funkcí - využití v proudech, jako je dada či surrealismus).

\section{Dance and Body/Self Performance}

Další okruh sledovaných problémů se týkal tanečního, pohybového umění a performancí těžících z tělesnosti, tělesného sebeuvědomování.

Meghan Forbes z Michiganské univerzity ve svém příspěvku „Staging Devětsil: Míra Holzbachová and the Czech Interwar Avant-garde“" postihla práci tanečnice a choreografky Míry Holzbachové coby členky Devětsilu a coby jedné z hlavních představitelek výrazového tance, jehož význam mezi válkami silně vzrůstal.

Dora Gremlicová z DAMU vzpomenula osobnost německého tanečníka a choreografa Kurta Joosse („Dancing Death: The Critical and Choreographic Perception of Kurt Jooss's The Green Table in Prague in the 1930s“), jehož protiválečné choreogra- fické dílo Zelený stůl z roku 1932 měli možnost vidět i diváci v Praze na vinohradské scéně v roce 1937, kam přijel Joossův soubor z Anglie, kde byl choreograf po nástupu Hitlera do funkce kancléře v emigraci.

Margarida Brito Alves z lisabonské Fakulty sociálních a humanitních věd připomněla dílo experimentální básnířky Salette Tavares (název př́spěvku zněl „Within and Beyond the Classroom. The Theatrical Educational Practises of Salette Tavares in 1974“), která se po demokratickém převratu v Portugalsku 1974 mohla věnovat i pedagogické práci. Autorka př́spěvku zmínila vedle umělecké činnosti i progresivní pedagogické metody S. Tavares, v nichž uplatnila svou schopnost komunikace a propojování edukace s performancí, tvorbu s prožívanou skutečností.

\section{Exchanges and Dialogues I}

Další blok třetího dne konference se věnoval problematice překladu.

Mariana Orawczak Kunešová z Ostravské univerzity ve svém př́íspěvku „André Breton on the French and Czech Stages" připomněla spisovatelův vliv na českou avantgardu, vydávání jeho díla v českých překladech a také některé české inscenace jeho dramatické tvorby (zejména v Osvobozeném divadle).

Petr Christov z FF UK („Wow, Have You Read It? Czech and French Avant-gardes on the Pages of French and Czech Journals and Revues") hovořil o fenoménu české a francouzské avantgardy, jak ji reflektovaly francouzské a české časopisy, ale také ty, které prrímo vznikly z popudu avantgardních autorů.

Michal Zahálka z Institutu umění Divadelního ústavu se detailně zabýval 
českými překlady francouzské avantgardní dramatiky básníka Jindřicha Hořejšího (,'Correct, but it's, a Translation.' Jindřich Hořejší and Contemporary French Drama“), postihl i teoretické aspekty překladů těchto děl, Hořejšího tvořivý, básnický, moderní přístup, který je inspirativní i pro další generace překladatelů.

\section{Exchanges and Dialogues II}

$\mathrm{V}$ poslední části konference promluvila Sarah Flock, která přednáší na univerzitách v Bruselu a v Lovani, o korespondenci Émila Verhaerena a Maurice Maeterlincka s českými umělci (Karlem Hugo Hilarem, Karlem a Josefem Čapkovými, Bohumilem Kubištou, Vlastislavem Hofmanem, Bedřichem Feuersteinem a dalšími). Ve své prezentaci k příspěvku („Brussels-Prague: Artistic Dialogue Between Two Peripheries“) ukázala také vzácné kostýmy z inscenace Svitání (1920, režie Karel Hugo Hilar), uložené v AML v Bruselu.

Tomaž Toporišič z Univerzity v Ljubljaně (příspěvek s názvem „The Slovene Avant-garde and the Conceptual Crisis of Europe") se zabýval méně známými aktivitami slovinských avantgardních umělců, provázaných $\mathrm{s}$ umělci $\mathrm{z}$ dalších zemí někdejšího jugoslávského prostoru, ale potýkajících se také od dvacátých let 20. století s blízkostí italského fašismu a s vlivem italského futurismu.
Závěr konference byl věnován malî́ce Toyen a virtuální prohlídce výstavy Snici rebelka v Národní galerii, vzniknuvší ve spolupráci s Hamburger Kunsthalle a Musée d'art moderne de Paris. Monumentální a objevnou expozicí provedla velmi detailně a poutavě kurátorka Anna Pravdová.

Brněnské konference si za léta svého pořádání získaly velký respekt teatrologické, potažmo uměnovědné obce pro nosnost a sevřenost témat, s nimiž přicházejí, pro vysokou organizační profesionalitu a preciznost a pritažlivou dramaturgii. $\mathrm{V}$ tomto konkrétním prrípadě se podařilo ukázat pestrobarevnost a oborou šíri záběru avantgardy i vliv, který měla a má v dalších historických obdobích. Na závěr si dovolím vyřrídit malý vzkaz: Jediné, co je možno slyšet jako výtku na adresu organizátorů, je skutečnost, že konference neprobíhají vedle angličtiny také v domácím jazyce (nedávná konference o R.U.R. a Bilé nemoci, pořádaná Institutem umění - Divadelním ústavem v Praze, potvrdila, že i v on-line podobě je dvojjazyčné provedení možné, a nijak to neumenšilo široký mezinárodní dosah setkání). Někteří badatelé starší generace, kteří se ve svém vzdělání orientovali většinou na německý a francouzský jazyk, ale kteří by do tématu měli mnoho co říci, se cítí být poněkud handicapováni... Necht je však tato námitka chápána nikoli jako kritika, ale jako možnost, jak př́padně zdokonalit dokonalé... 